\title{
The Dog Days of COVID-19
}

An animal's eyes have the power to speak a great language.

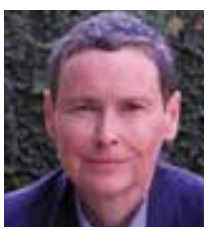

Cynthia M.A. Geppert, MD, Editor-in-Chief Correspondence: Cynthia Geppert (ethicdoc@ comcast.net)
$\mathrm{T}$ he editorials I have written so far in this series on COVID-19 have been on weighty topics as befits the serious situation of the pandemic, which as of June 30, 2020 had taken more than 500,000 lives across the globe and caused anguish and sorrow such as the world has not known since the 1918 influenza pandemic. ${ }^{2}$

The human spirit can bear only so much distress and tragedy before it is bowed and unable to stand. Stand though we must; not just against the inanimate invasion of viruses from the outside, but also our own endemic national tensions and conflicts. A periodic lifting of our burdens and a recharging of our psychological and spiritual energies are crucial to the resilience and flexibility that are necessary to walk the long difficult road ahead of us as a nation and as public servants in health care. This column takes a lighter look at COVID-19 and considers the restorative role companion animals, especially, for me, my beloved canines, have played in caring for and about us humans during the pandemic.

You will likely read this editorial during the official dog days of summer, which run from July 22 to August 22. We all may imagine a big dog laying on a porch in the American South while his owners drink lemonade and quietly rock in chairs watching the long lazy days pass in a simpler time.

However pleasant this bucolic picture, it has little to do with the origin of the expression, which dates back to ancient Greece. The dog refers not to our literal furry friends but, according to National Geographic (and who should know better), to the position of the "dog star" in a constellation in the night sky. ${ }^{3}$ Unfortunately, we cannot completely get away from the sobering theme of the pandemic: The rise of the star to prominence during the peak of the Mediterranean summer's heat was a period associated with disaster and illness.

Real dogs, cats, and assorted other so-called

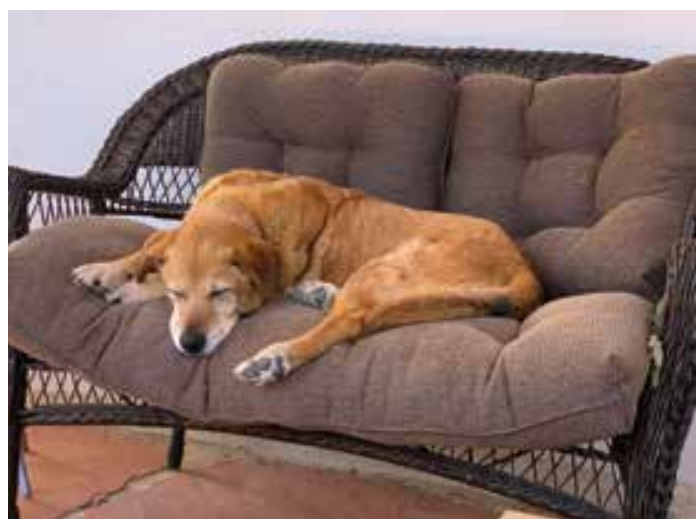

pandemic pets, though, have been another type of star in this difficult period. Early in the shelter-in-place, pet adoptions from city and county animal shelters and rescue organizations skyrocketed. ${ }^{4}$ Although animal welfare experts have legitimate concerns that some of these adoptees will be surrendered if there is ever a return to normal. For now many people feel it is the perfect time to adopt, precisely because they now have space to bring a new member into the family. Before adopting, as a recent $\mathrm{Na}$ tional Public Radio report emphasized, individuals should consider whether they truly have the resources both material and emotional to care for a pet. ${ }^{5}$ For those who take stock honestly and believe they have the room in their heart and budget, rescuing a companion is good psychological news, arguably even more for the human than for the animal.

Sheltering-in-place has reduced the transmission of the virus, which scientists estimate has saved thousands of lives. ${ }^{6}$ But it also has triggered a second health crisis, this time of mental health with an unprecedented increase in rates of depression, anxiety, suicide attempts, and substance use that is expected to worsen over the coming months and years. ${ }^{7}$ Companion animals certainly cannot solve this complex and mammoth public health problem; however, they can contribute in simple and small yet very significant ways to the mental health of individuals. ${ }^{8}$ 
Caring for a pet who shows unconditional love and loyalty to you can reduce isolation; foster hope; provide meaning, comfort, and cheer to you when you are down or afraid; and offer a routine and reason to get out of bed every day and take a walk outside. Research shows that those positive effects can decrease the risk of the very mental health conditions that are now plaguing us in such alarming numbers. ${ }^{9,10}$

"How many more lives are we willing to sacrifice in the name of containing the virus?" Elinore McCance-Katz, MD, PhD, the nation's top mental health official ominously asked about the potential effects of another shutdown during a cabinet meeting. ${ }^{11}$ For some of us, a companion animal who does not require physical distancing (at least when you are healthy) may permit us to prevent the spread of the virus while protecting our mental health.

Nor is emotional support the only clinical way in which animals are helping pandemicbeleaguered humans. There is a low risk we can infect household pets, and dogs are not likely to transmit the virus. In fact, they even can be trained to serve as highly efficient virus testers who don't need scarce reagents or carry high price tags-just a pat on the head and an occasional treat. ${ }^{12}$ Medscape reported that clinical trials starting in the United Kingdom are set to evaluate the accuracy of these "bio-detection" dogs. The story quotes a leading British public health official as saying, "Properly trained sniffer dogs could revolutionise our approach to this whole pandemic, screening 250 people an hour for the virus." 13

Canines are not only healers who can ease our troubles through the pandemic but also peacemakers. As injustice and violence rock the country, we would do well to imitate their attitudes of nonjudgmental acceptance. "Dogs are our link to paradise. They do not know evil or jealousy or discontent," wrote novelist Milan Kundera. "To sit with a dog on a hillside on a glorious afternoon is to be back in Eden, where doing nothing was not boring-it was peace." 14
Those indeed would be dog days as when better nature we sometimes share with animals prevailed.

\section{Disclaimer}

The opinions expressed herein are those of the author and do not necessarily reflect those of Federal Practitioner, Frontline Medical Communications Inc., the US Government, or any of its agencies.

\section{References}

1. Buber M. I and Thou. Kaufmann W, trans. New York: Charles Scribner's Sons: 1970:144.

2. World Health Organization. Coronavirus disease (COVID19). Situation report-153. https://www.who.int/docs /default-source/coronaviruse/situation-reports/20200621 -covid-19-sitrep-153.pdf?sfvrsn=c896464d_2. Published June 21, 2020. Accessed June 22, 2020.

3. Little B. Why do we call them the 'dog days' of summer. National Geographic. July 10, 2015. https://www .nationalgeographic.com/news/2015/07/150710-dog -days-summer-sirius-star-astronomy-weather-language. Accessed June 21, 2020.

4. Ellis EG. Thanks to sheltering in place, animal shelters are empty. https://www.wired.com/story/coronavirus-pet -adoption-boom. Published April 10, 2020. Accessed June 21, 2020.

5. Balaban S. Should I adopt a dog during the coronavirus crisis? Read this first. https://www.npr .org/2020/05/08/853088872/should-i-adopt-a-dog-during -the-coronavirus-crisis-read-this-first. Published May 11, 2020. Accessed June 21, 2020

6. Hsiang S, Allen D, Annan-Phan S, et al. The effect of large-scale anti-contagion policies on the COVID19 pandemic [published online ahead of print, 2020 Jun 8]. Nature. 2020;10.1038/s41586-020-2404-8. doi:10.1038/s41586-020-2404-8

7. Galea S, Merchant RM, Lurie N. The Mental Health Consequences of COVID-19 and Physical Distancing: The Need for Prevention and Early Intervention [published online ahead of print, $2020 \mathrm{Apr} 10]$. JAMA Intern Med. 2020;10.1001/jamainternmed.2020.1562. doi:10.1001/jamainternmed.2020.1562

8. Rajewski G. How animals help us during the COVID-19 pandemic. https://now.tufts.edu/articles/how-animals-help -us-during-covid-19-pandemic. Published Mach 30, 2020. Accessed June 21, 2020

9. Fitzpatrick KM, Harris C, Drawve G. Fear of COVID-19 and the mental health consequences in America [published online ahead of print, 2020 Jun 4]. Psychol Trauma. 2020;10.1037/ tra0000924. doi:10.1037/tra0000924

10. Rajkumar RP. COVID-19 and mental health: A review of the existing literature [published online ahead of print, 2020 Apr 10]. Asian J Psychiatr. 2020;52:102066. doi:10.1016/j.ajp.2020.102066

11. The White House. Remarks by President Trump in cabinet meeting. https://www.whitehouse.gov/briefings-statements /remarks-president-trump-cabinet-meeting-17. Published May 19, 2020. Accessed June 21, 2020

12. Centers for Disease Control and Prevention. Coronavirus Disease 2019 (COVID-19). COVID -19 and animals. https://www .cdc.gov/coronavirus/2019-ncov/daily-life-coping/animals .html. Updated June 22, 2020. Accessed June 24, 2020.

13. Russell P. Could bio-detection dogs sniff out COVID-19 infection. https://www.medscape.com/viewarticle/930652. Published May 17, 2020. Accessed June 21, 2020.

14. Kundera M. The Unbearable Lightness of Being. New York: Harper \& Row; 1984. 